\title{
Determination of Vitamin D Status in a Population of Ecuadorian Subjects
}

\author{
G. Maldonado, ${ }^{1}$ C. Paredes, ${ }^{1}$ R. Guerrero, ${ }^{1}$ and C. Ríos $^{2}$ \\ ${ }^{1}$ Universidad de Especialidades Espíritu Santo, Km. 2.5 Vía la Puntilla, Samborondón, Ecuador \\ ${ }^{2}$ Centro de Reumatología y Rehabilitación, El Oro y Ambato 1004, Guayaquil, Ecuador
}

Correspondence should be addressed to G. Maldonado; genesismaldonadovelez92@gmail.com

Received 19 May 2017; Accepted 16 July 2017; Published 16 August 2017

Academic Editor: Hind A. Beydoun

Copyright (c) 2017 G. Maldonado et al. This is an open access article distributed under the Creative Commons Attribution License, which permits unrestricted use, distribution, and reproduction in any medium, provided the original work is properly cited.

\begin{abstract}
Introduction. Vitamin D is a preprohormone known to play a key role in phosphocalcic metabolism; its main source comes from the synthesis at the skin level by ultraviolet (UV) radiation. Objective. The purpose of this study was to determine the levels of vitamin $\mathrm{D}$ in an Ecuadorian population. Materials and Methods. Retrospective study of Ecuadorian subjects from the city of Guayaquil, who had an initial study of $25(\mathrm{OH})$-D serum, as the indicator of Vitamin D status, in the period of 2015-2016. Results. A total of 269 Ecuadorian subjects were analyzed, with a mean age of $54.73 \pm 16.58 ; 85 \%$ (229) were females and $15 \%$ (41) males; mean vitamin D was $27.29 \pm 10.12 \mathrm{ng} / \mathrm{dl}$ [6.41-88.74]; $70 \%$ of the population showed levels below $30 \mathrm{ng} / \mathrm{dL}$ of vitamin D, whereas only $30 \%$ (81) had normal values. 69\% (185) had levels between 29 and $10 \mathrm{ng} / \mathrm{dl}$ and 1\% (3) levels below $10 \mathrm{ng} / \mathrm{dl}$. High levels of vitamin D were evidenced in the summer months in relation to the winter months. Conclusion. It is evident that, despite the location of Ecuador and the intensity of UV rays it receives throughout the year, Ecuadorian subjects have insufficient levels of vitamin D.
\end{abstract}

\section{Introduction}

Vitamin D is a preprohormone known to play a key role in the metabolism of phosphates and calcium. Its main source is the synthesis by ultraviolet (UV) radiation in the skin $[1,2]$. The intensity of UV rays will depend on the height of the sun, latitude, cloudiness, altitude, ozone layer, and soil reflection [3].

Ecuador is located on the equator at a latitude of -0.95 , with two seasons: winter (January-April) and summer (May-December). The solar radiation index is $10-11 \mathrm{UV}$, which is considered as very high radiation levels; however, the general population takes measures to avoid sun exposure which results in insufficient levels of vitamin $\mathrm{D}$. The objective of this study was to determine vitamin $\mathrm{D}$ status by measuring serum calcidiol $(25(\mathrm{OH})-\mathrm{D})$ in an Ecuadorian population that had attended a first consultation at a Rheumatology Center.

\section{Materials and Methods}

Retrospective study of Ecuadorian subjects from the city of Guayaquil, Ecuador, who had an initial study of serum 25
(OH)-D, as the indicator of vitamin D status, from 2015 to 2016.

\section{Determination of Vitamin D}

The $25(\mathrm{OH})-\mathrm{D}$ serum levels of the patients had been measured in the same laboratory. Samples were analyzed by the chemiluminescence method with an Advia Centaur ${ }^{\circledR}$ assay system. Serum $25(\mathrm{OH})$-D levels are not standardized for each population; however, the following (1.4-6) are considered:

(i) Ideal: $30-40 \mathrm{ng} / \mathrm{dL}$

(ii) Deficiency: $30-20 \mathrm{ng} / \mathrm{dL}$

(iii) Insufficiency: $20-10 \mathrm{ng} / \mathrm{dL}$

(iv) Severe insufficiency: $<10 \mathrm{ng} / \mathrm{dL}$.

The patients were from the city of Guayaquil located in Guayas province, at six meters above sea level and at a latitude of -0.95 , with a solar exposure index of $10-11 \mathrm{UV}$.

3.1. Statistical Analysis. The data was analyzed using the statistical program SPSS v 22, with $T$-test of two tails for the 
TABLE 1: Demographic data and $25(\mathrm{OH})-\mathrm{D}$ levels.

\begin{tabular}{lccc}
\hline & $n=269$ & $\%$ & $p \leq 0.001$ \\
\hline Demographic data & & & \\
$\quad$ Women & 228 & 85 & - \\
$\quad$ Men & 41 & 15 & - \\
$\quad$ Mean age & $54.73 \pm 16.58$ & $p \leq 0.001$ \\
25 (OH)-D & & & \\
$\quad$ Normal & 81 & 30 & $p \leq 0.001$ \\
Deficiency & 141 & 53 & $p \leq 0.001$ \\
Insufficiency & 44 & 16 & $p \leq 0.001$ \\
$\quad$ Severe insufficiency & 3 & 1 & $p \leq 0.001$ \\
\hline Mean & \multicolumn{2}{c}{$27.29 \pm 10.12[6.41-88.74]$} \\
Women & \multicolumn{3}{c}{$27.01 \pm 9.72[6.41-75.54]$} \\
Men & \multicolumn{2}{c}{$28.89 \pm 12.18[11.78-88.75]$} \\
\hline
\end{tabular}

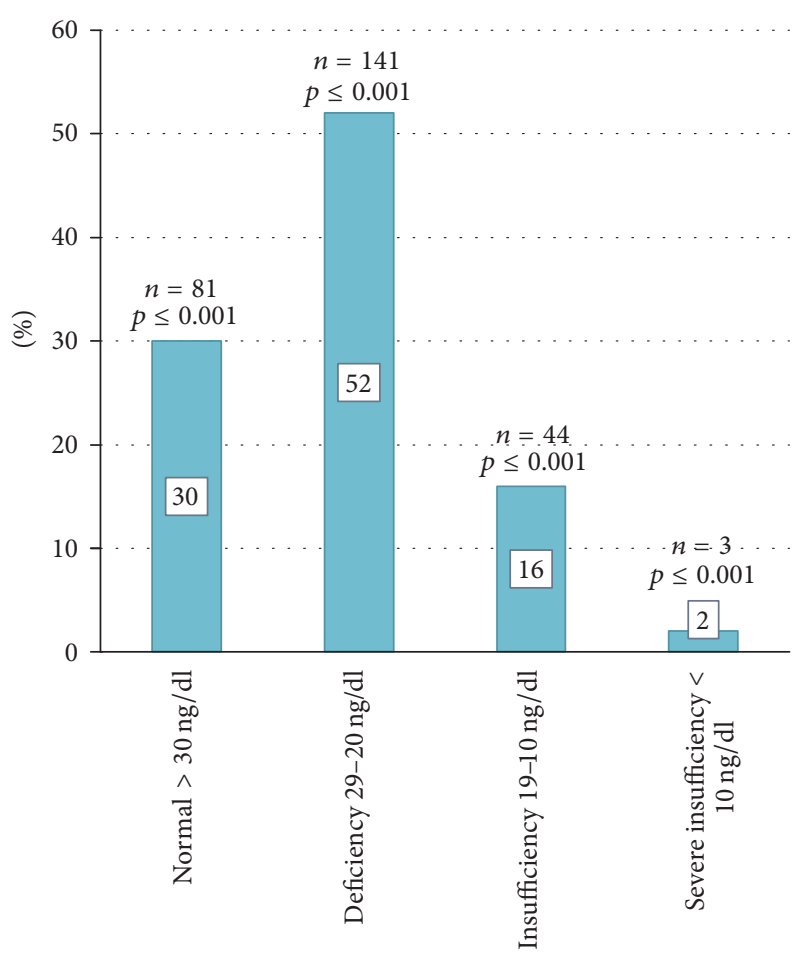

Figure 1: $25(\mathrm{OH})-\mathrm{D}$ levels, as indicator of vitamin D status, in Ecuadorian subjects.

quantitative variables and chi-square and logistic regression for the qualitative variables. $P$ values below 0.01 were considered statistically significant.

\section{Results}

269 Ecuadorian subjects were analyzed, with a mean age of $54.73 \pm 16.58 ; 85 \%$ [229] were female and $15 \%$ [41] male; mean level of $25(\mathrm{OH})-\mathrm{D}$ was $27.29 \pm 10.12 \mathrm{ng} / \mathrm{dl}$ [6.41-88.74] (Table 1); 70\% of the population showed levels below $30 \mathrm{ng} / \mathrm{dL}$ of $25(\mathrm{OH})-\mathrm{D}$, whereas only $30 \%$ (81) had normal values. $69 \%$ (185) had levels between 29 and $10 \mathrm{ng} / \mathrm{dl}$ and 1\% (3) had levels below $10 \mathrm{ng} / \mathrm{dl}$ (Figure 1).
TABLE 2: Age groups.

\begin{tabular}{lccc}
\hline Age group & $n=269$ & $\%$ & $p \leq 0.001$ \\
\hline Children, adolescents $<$ 18 years old & 4 & 1.5 & 0.001 \\
Young adults 18-35 years old & 44 & 16.4 & 0.001 \\
Adults 36-64 years old & 133 & 49.4 & $p \leq 0.001$ \\
Elderly $>$ 65 years old & 88 & 32.7 & 0.001 \\
\hline
\end{tabular}

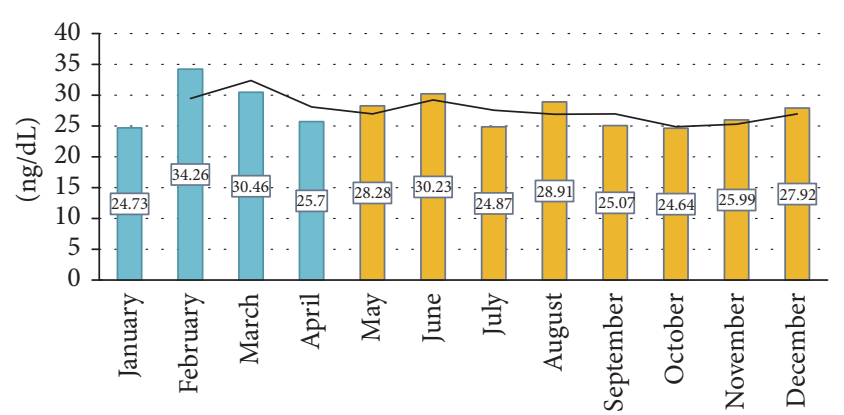

2016

Figure 2: $25(\mathrm{OH})$-D levels during the 12 months of the year. Months with the lowest sun exposure: January-April (winter); months with the highest sun exposure: May-December (summer).

Men had higher levels of $25(\mathrm{OH})-\mathrm{D}$ than women, but levels in both sexes were deficient with a mean of $27.01 \pm 9.72$ and $28.89 \pm 12.18$, respectively.

Higher levels of $25(\mathrm{OH})-\mathrm{D}$ were observed in the summer months in relation to the winter months, with February being the month with the highest $25(\mathrm{OH})-\mathrm{D}$ level $34.26 \pm 12.7$ (Figure 2).

Patients were divided into age groups according to the WHO scale [4] (Table 2) and $25(\mathrm{OH})$-D levels were determined: children-adolescent $21.04 \pm 8.01$, young adults $23.92 \pm$ 5.48 , adults $27.26 \pm 10.70$, and elderly $29.31 \pm 10.65$ (Figure 3 ).

\section{Discussion}

This is a descriptive study of an Ecuadorian population in which levels of $25(\mathrm{OH})-\mathrm{D}$, as an indicator of vitamin D status, were determined. $70 \%$ of the population showed levels below $30 \mathrm{ng} / \mathrm{dl}$, considered insufficient.

The origin of the population is an important factor when evaluating vitamin D status, because Ecuador is located on the equator at a latitude of -0.95 , where the radiation and intensity of UV rays are greater. You would expect the population to have sufficient levels of vitamin D; however, Ecuadorians take measures to avoid sun exposure.

Common sunscreens absorb solar radiation. It has been shown that a sunscreen with a protection factor (SPF) of 30 can absorb up to 95-98\% of UV radiation, which reduces the production of vitamin D3 in 95-98\% [1]. A study by Matsuoka et al. showed that a sunscreen with an SPF of 8 significantly lowered serum vitamin D3 levels $[5,6]$. Also, Matsouka et al. evaluated vitamin D levels in a population of farmers who, because of a significant history 


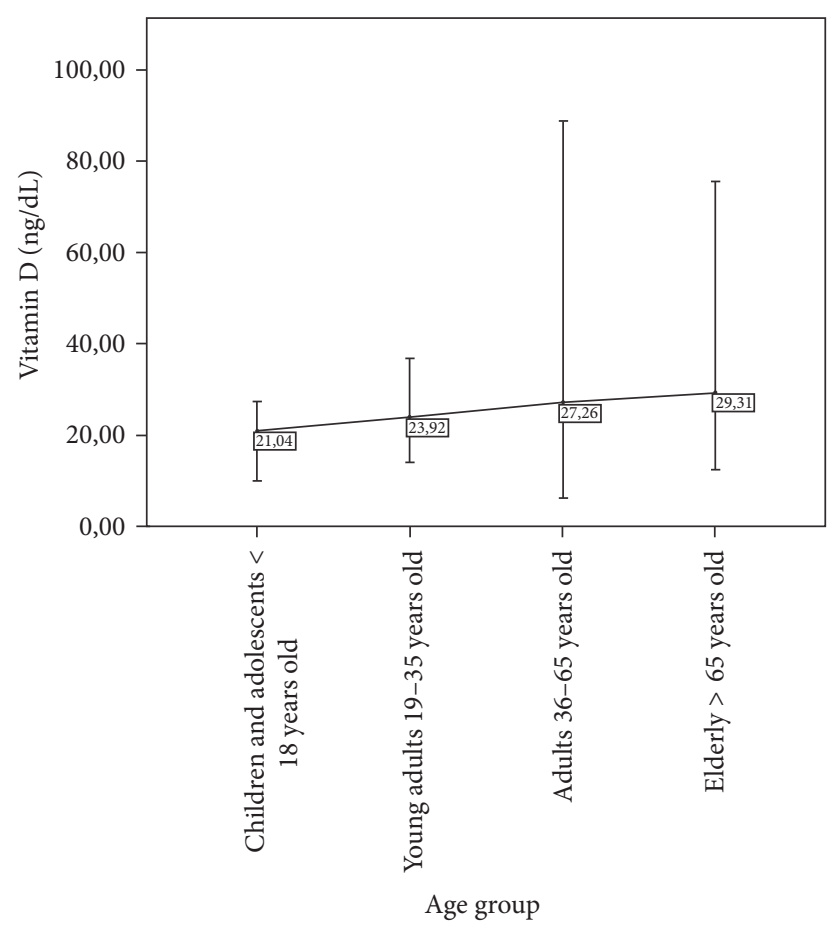

Figure 3: Mean $25(\mathrm{OH})-\mathrm{D}$ levels in the age groups.

of melanoma, took sun protection measures before performing outdoor activities. It was shown that farmers had deficient levels of vitamin D compared to a control group [5].

A study conducted in Atahualpa, a village located on the Ecuadorian coast, determined $25(\mathrm{OH})$-D levels in 220 subjects, of which $25 \%$ had levels below $20 \mathrm{ng} / \mathrm{ml}$ and was directly related to ischemic events and diffuse subcortical brain damage [7], another reason why the determination and management of vitamin $\mathrm{D}$ is essential.

Climatic seasons have a significant influence on the production of cutaneous vitamin D [1]. It has been shown that, in countries with four climatic seasons, vitamin D levels vary. In England, for example, the peak of vitamin D levels occurs in the month of September with an average of $30 \mathrm{ng} / \mathrm{dl}$ and the lowest levels occur in February with an average of $14 \mathrm{ng} / \mathrm{dL}$ [8]. In cohorts of countries with similar climates like Denmark, vitamin D levels are deficient during the winter months [9]; this data differs from our study, where the mean vitamin D level during the winter was $29.29 \pm 3.89$ and in the summer, an average of $27.13 \pm 3.98$. Vitamin D changes in our population are due to the fact that Ecuador consists of two climatic seasons: winter and summer, where UV rays are constant throughout the year (10-11 UV). According to the climatic classification of Köppen [10], Ecuador has a tropical climate characterized by temperatures above $27 \mathrm{C}$ with the difference between winter and summer being the amount of fluvial precipitation. Between the months of January and April there are strong and frequent precipitations, whereas in the months between May and December the precipitation is minimal [11].
A study by dermatologists in Australia showed that approximately $87 \%$ of Australians after summer had vitamin D levels below $20 \mathrm{ng} / \mathrm{dL}$ [12].

Reports from Mexico, Europe, Asia, India, and Africa show that more than $50 \%$ of the world's population is at risk of hypovitaminosis $\mathrm{D}[1,13,14]$, making it a pandemic condition $[1,15]$. Data published by the US Centers for Disease Control and Prevention (CDC) show that approximately 32\% of children and adults have a significant vitamin $\mathrm{D}$ deficiency $<20 \mathrm{ng} / \mathrm{ml}$, with hypovitaminosis being more prevalent than obesity in the United States, which is why basic foods such as dairy products were supplemented with vitamin D [12].

As for the age group, vitamin $\mathrm{D}$ levels have been shown to be inversely related to age $[16,17]$, and its production after the sixth decade of life declines [18]. Because of this, supplementation measures are taken in the elderly. In our study, the mean vitamin D level in the elderly group was higher than the other groups. We infer that this is because this group was probably undergoing vitamin D supplementation.

Studies have demonstrated the utility of vitamin D in cardiovascular diseases [19-22], diabetes [23-25], rheumatic and immunological diseases [26-32], hypertension [22, 33, $34]$, metabolic disorders [35, 36], cancer [37-39], infectious diseases triggered by autoimmune disorders [31], and some neuropsychiatric conditions [40], highlighting the importance of measuring this parameter for a more comprehensive assessment of the patient.

The advantages of our study were that the subjects admitted to the study were not institutionalized, the technique used for the determination of vitamin $\mathrm{D}$ was universal, and the origin of the population was exclusively the city of Guayaquil. Within the limitations we consider the lack of sun exposure data and specific measures of sun protection. However, the stated objectives were reached, thus determining that $70 \%$ of the population studied showed deficient levels of 25 $(\mathrm{OH})-\mathrm{D}$. More studies of vitamin D status determination are needed in other cities of Ecuador with different geographic characteristics such as the Andes and Amazon region.

\section{Conclusions}

It is evident that despite the location of Ecuador and the intensity of UV rays it receives throughout the year, Ecuadorian subjects have insufficient levels of vitamin $D$. In the summer months vitamin D levels are higher compared to winter months. Also, vitamin D levels are higher in the elderly compared to other age groups.

\section{Conflicts of Interest}

The authors declare no conflicts of interest.

\section{References}

[1] M. F. Holick, "Vitamin D deficiency," The New England Journal of Medicine, vol. 357, no. 3, pp. 266-281, 2007.

[2] P. Lips, "Vitamin D physiology," Progress in Biophysics and Molecular Biology, vol. 92, pp. 4-8, 2006. 
[3] Organización Mundial de la Salud, "Indice UV solar mundial: guía práctica. Recomendación conjunta de: Organización Mundial de la Salud, Organización Meterológica Mundial, Programa de las Naciones Unidas para el Medio Ambiente," Comisión Internacional de Protección contra la Radiación no Ion, 2003.

[4] O. B. Ahmad, C. Boschi-pinto, and A. D. Lopez, "Age standardization of rates: a new WHO standard," GPE Discuss Pap Ser, vol. 31, pp. 1-14, 2001, http://www.who.int/healthinfo/paper31.pdf.

[5] L. Y. Matsuoka, J. Wortsman, N. Hanifan, and M. F. Holick, "Chronic Sunscreen Use Decreases Circulating Concentrations of 25-Hydroxyvitamin D: A Preliminary Study," Archives of Dermatology, vol. 124, no. 12, pp. 1802-1804, 1988.

[6] S. Matsuoka, L. Ide, J. Wortsman, J. MacLaughlin, and M. Holick, "Sunscreens suppress cutaneous vitamin D3 synthesis," Journal of Clinical Endocrinology and Metabolism, vol. 64, pp. 1165-1168, 1987.

[7] O. H. Del Brutto, R. M. Mera, J. Macias, G. Morales, and M. Zambrano, "Cerebrovascular correlates of vitamin D deficiency in older adults living near the equator: Results from the Atahualpa project," International Journal of Stroke, vol. 10, no. 8, pp. 1301-1303, 2015.

[8] E. Hyppönen and C. Power, "Hypovitaminosis D in British adults at age $45 \mathrm{y}$ : nationwide cohort study of dietary and lifestyle predictors," The American Journal of Clinical Nutrition, vol. 85, pp. 860-868, 2007.

[9] C. Brot, P. Vestergaard, N. Kolthoff, J. Gram, A. P. Hermann, and O. H. Sørensen, "Vitamin D status and its adequacy in healthy Danish perimenopausal women: relationships to dietary intake, sun exposure and serum parathyroid hormone," British Journal of Nutrition, vol. 86, supplement 1, pp. S97-S103, 2001.

[10] M. Kottek, J. Grieser, C. Beck, B. Rudolf, and F. Rubel, "World map of the Köppen-Geiger climate classification updated," Meteorologische Zeitschrift, vol. 15, no. 3, pp. 259-263, 2006.

[11] T. L. McKnight and D. Hess, "Climate zones and types. physical geography: a landscape appreciation," NJ: Prentice Hall, pp. 205208, 2000.

[12] D. Czarnecki, C. J. Meehan, and F. Bruce, "The vitamin D status of Australian dermatologists," Clinical and Experimental Dermatology, vol. 34, no. 5, pp. 624-625, 2009.

[13] A. Looker, C. Johnson, D. Lacher et al., "Vitamin D status: United States, 2001-2006," NCHS Data Brief, vol. 56, 2011.

[14] A. Hossein-Nezhad and M. F. Holick, "Optimize dietary intake of vitamin D: an epigenetic perspective," Current Opinion in Clinical Nutrition and Metabolic Care, vol. 15, pp. 567-579, 2012, http://dx.doi.org/10.1097/MCO.0b013e3283594978.

[15] M. F. Holick and T. C. Chen, "Vitamin D deficiency: a worldwide problem with health consequences," American Society for Clinical Nutrition, vol. 87, no. 4, pp. 1080S-1086S, 2008, http://ajcn.nutrition.org/content/87/4/1080S.long.

[16] J. MacLaughlin and M. F. Holick, "Aging decreases the capacity of human skin to produce vitamin D3," The Journal of Clinical Investigation, vol. 76, no. 4, pp. 1536-1538, 1985.

[17] M. Wacker and M. F. Holick, "Sunlight and Vitamin D: a global perspective for health," Dermato-Endocrinology, vol. 5, no. 1, pp. 51-108, 2013.

[18] M. F. Holick, L. Matsuoka, and J. Wortsman, "Age, vitamin D, and solar ultraviolet," The Lancet, vol. 2, pp. 1104-1105, 1989.

[19] J. L. Anderson, H. T. May, B. D. Horne et al., "Intermountain Heart Collaborative (IHC) Study Group. Relation of Vitamin D Deficiency to Cardiovascular Risk Factors, Disease Status, and Incident Events in a General Healthcare Population," The American Journal of Cardiology, vol. 106, no. 7, pp. 963-968, 2010.

[20] L. Wang, Y. Song, J. E. Manson et al., "Circulating 25-HydroxyVitamin D and risk of cardiovascular disease: A meta-analysis of prospective studies," Circulation: Cardiovascular Quality and Outcomes, vol. 5, no. 6, pp. 819-829, 2012.

[21] S. Pilz, A. Tomaschitz, and W. März, "Vitamin D, cardiovascular disease and mortality," Clinical Endocrinology, vol. 75, pp. 575$584,2011$.

[22] A. G. Pittas, M. Chung, T. Trikalinos et al., "Systematic review: vitamin D and cardiometabolic outcomes," Annals of Internal Medicine, vol. 152, no. 5, pp. 307-314, 2010.

[23] J. Mitri, M. D. Muraru, and A. G. Pittas, "Vitamin D and type 2 diabetes: a systematic review," European Journal of Clinical Nutrition, vol. 65, no. 9, pp. 1005-1015, 2011.

[24] H. Khan, S. Kunutsor, and O. Franco, "Vitamin D, type 2 diabetes and other metabolic outcomes: a systematic review and meta-analysis of prospective studies," The Proceedings of the Nutrition Society, vol. 30, pp. 1-9, 2013.

[25] A. G. Pittas, D. M. Nathan, J. Nelson et al., "Plasma 25hydroxyvitamin $\mathrm{D}$ and progression to diabetes in patients at risk for diabetes: An ancillary analysis in the diabetes prevention program," Diabetes Care, vol. 35, no. 3, pp. 565-573, 2012.

[26] P. Gatenby, R. Lucas, and A. Swaminathan, "Vitamin D deficiency and risk for rheumatic diseases: An update," Current Opinion in Rheumatology, vol. 25, no. 2, pp. 184-191, 2013.

[27] C. Jesus, D. Feder, and M. Peres, "The role of vitamin D in pathophysiology and treatment of fibromyalgia," Current Pain and Headache Reports, vol. 17, p. 355, 2013.

[28] Y. Zhang, D. Y. M. Leung, B. N. Richers et al., "Vitamin $\mathrm{D}$ inhibits monocyte/macrophage proinflammatory cytokine production by targeting MAPK phosphatase-1," Journal of Immunology, vol. 188, no. 5, pp. 2127-2135, 2012.

[29] C. A. J. Cavalcanti, J. de Azevêdo Silva, W. de Barros Pita et al., "Vitamin D receptor polymorphisms and expression profile in rheumatoid arthritis brazilian patients," Molecular Biology Reports, vol. 43, no. 1, pp. 41-51, 2016.

[30] L. L. W. Ishikawa, P. M. Colavite, C. Fraga-Silva T. F. de, L. A. N. Mimura, T. G. D. França, S. F. G. Zorzella-Pezavento et al., "Vitamin D Deficiency and Rheumatoid Arthritis. Clin Rev Allergy Immunol [Internet]. Clinical Reviews," in Clinical Reviews in Allergy \& Immunology, pp. 1-16, Springer, 2016, http://link.springer.com/10.1007/s12016-016-8577-0.

[31] M. Hewison, "Vitamin D and immune function: autocrine, paracrine or endocrine?" Scandinavian Journal of Clinical and Laboratory Investigation, vol. 72, no. sup243, pp. 92-102, 2012, http://www.tandfonline.com/doi/pdf/10.3109/00365513.2012 .682862 ? needAccess $=$ true.

[32] J. A. Reynolds and I. N. Bruce, "Vitamin D treatment for connective tissue diseases: hope beyond the hype?" Rheumatology, pp. 1-9, 2016, http://www.ncbi.nlm.nih.gov/pubmed/27179106.

[33] R. Scragg, M. Sowers, and C. Bell, "Serum 25-hydroxyvitamin D, ethnicity, and blood pressure in the Third National Health and Nutrition Examination Survey," American Journal of Hypertension, vol. 20, no. 7, pp. 713-719, 2007.

[34] A. Burgaz, N. Orsini, S. C. Larsson, and A. Wolk, "Blood 25hydroxyvitamin $\mathrm{D}$ concentration and hypertension: a metaanalysis," Journal of Hypertension, vol. 29, no. 4, pp. 636-645, 2011. 
[35] E. Hyppönen, B. J. Boucher, D. J. Berry, and C. Power, "25hydroxyvitamin D, IGF-1, and metabolic syndrome at 45 years of age A cross-sectional study in the 1958 british birth cohort," Diabetes, vol. 57, no. 2, pp. 298-305, 2008.

[36] B. J. Boucher, "Is vitamin D status relevant to metabolic syndrome?" Dermato-Endocrinology, vol. 4, no. 2, pp. 212-224, 2012.

[37] C. F. Garland, E. D. Gorham, S. B. Mohr, and F. C. Garland, "Vitamin D for cancer prevention: global perspective," Annals of Epidemiology, vol. 19, no. 7, pp. 468-483, 2009.

[38] C. F. Garland, C. B. French, L. L. Baggerly, and R. P. Heaney, "Vitamin D supplement doses and serum 25-hydroxyvitamin $\mathrm{D}$ in the range associated with cancer prevention," Anticancer Research, vol. 31, no. 2, pp. 607-611, 2011, http://ar.iiarjournals .org/content/31/2/607.long.

[39] W. B. Grant, "Relation between prediagnostic serum 25hydroxyvitamin D level and incidence of breast, colorectal, and other cancers," Journal of Photochemistry and Photobiology B: Biology, vol. 101, no. 2, pp. 130-136, 2010.

[40] D. J. Llewellyn, I. A. Lang, K. M. Langa et al., "Vitamin D and risk of cognitive decline in elderly persons," Archives of Internal Medicine, vol. 170, no. 13, pp. 1135-1141, 2010. 


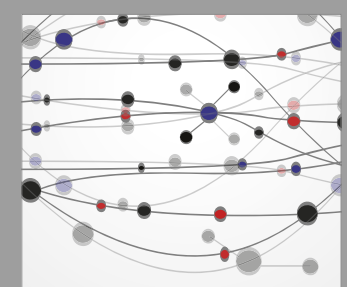

The Scientific World Journal
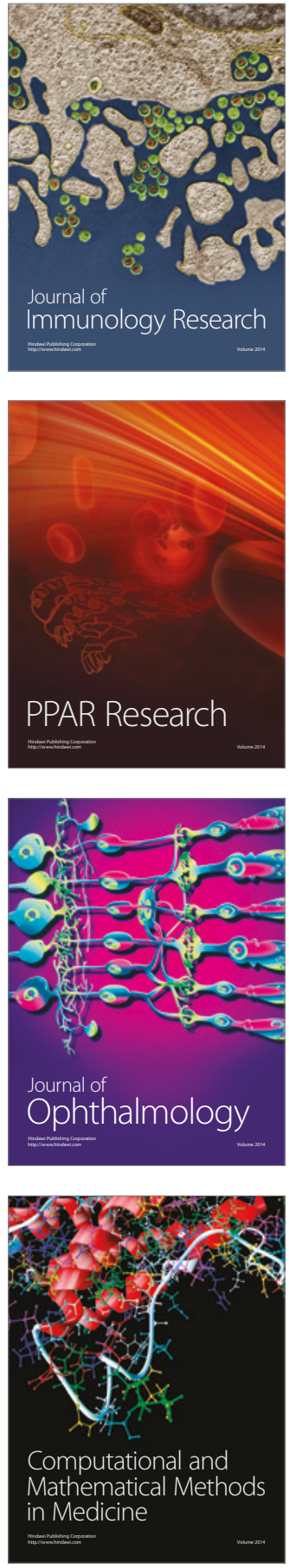

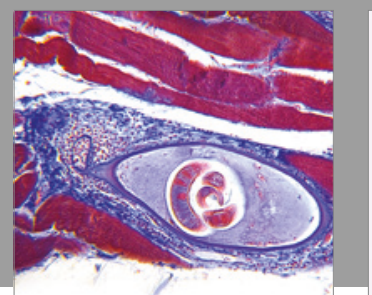

Gastroenterology Research and Practice
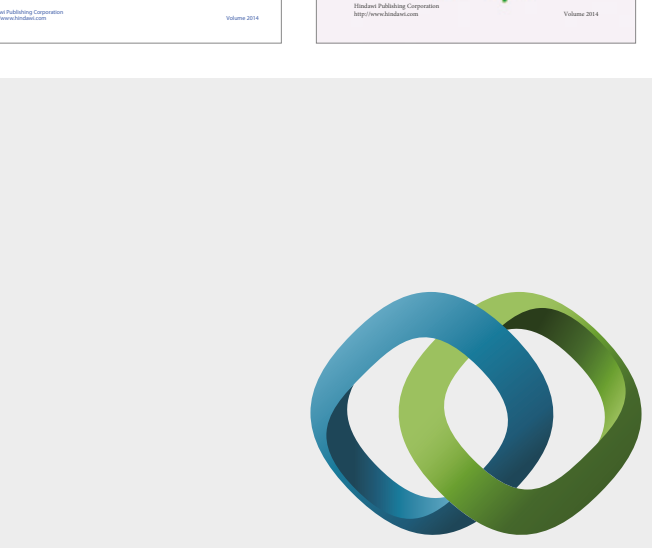

\section{Hindawi}

Submit your manuscripts at

https://www.hindawi.com
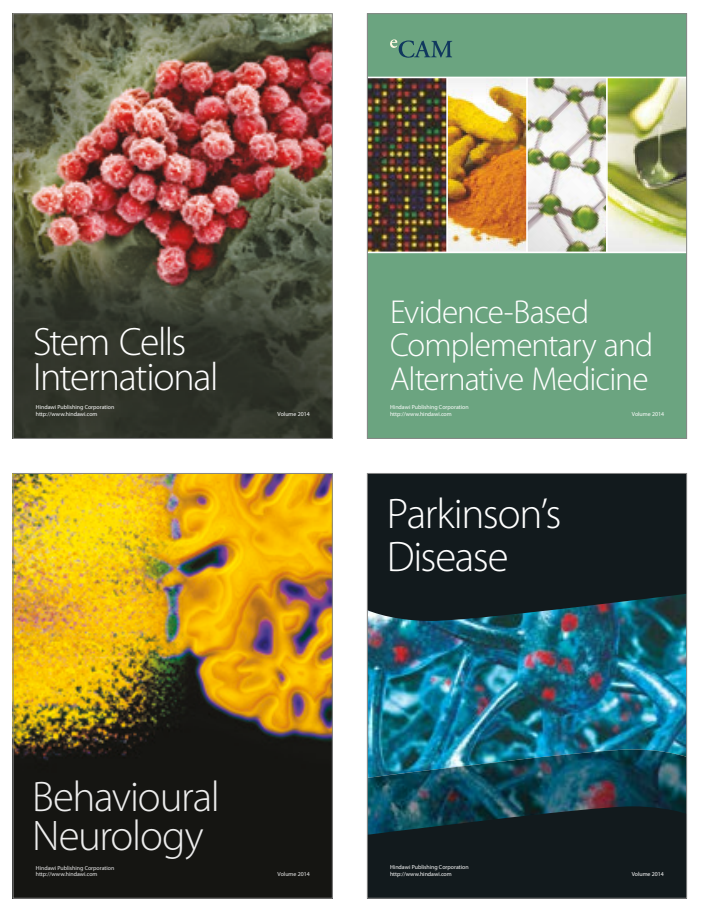
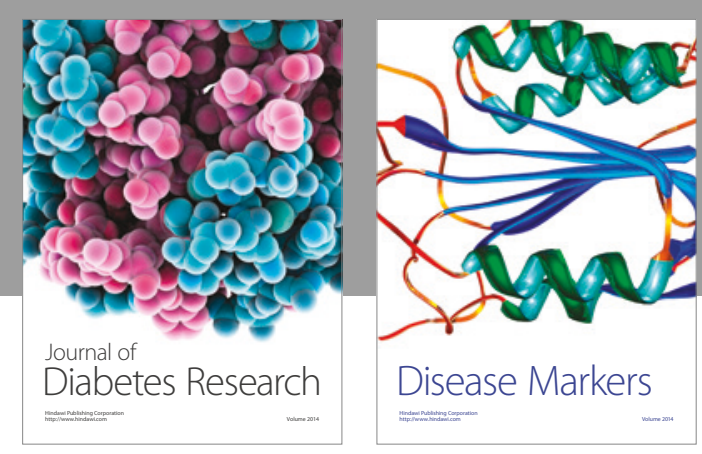

Disease Markers
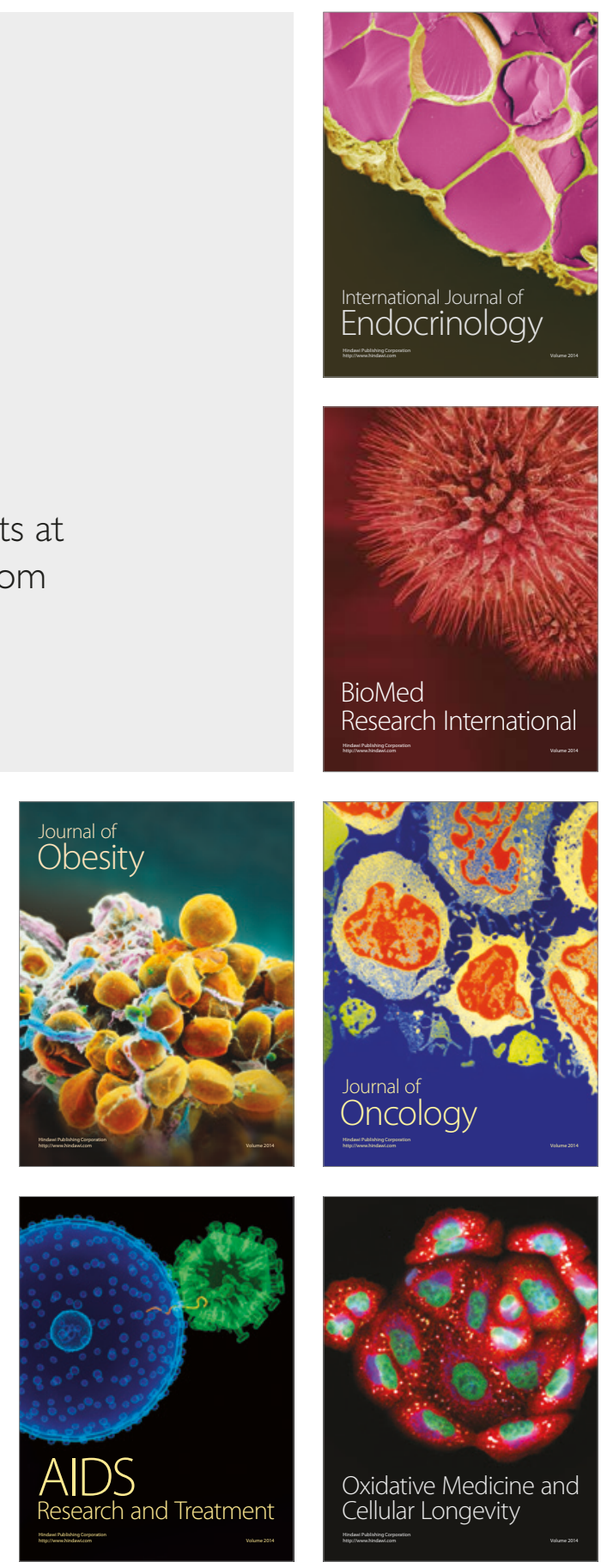